\title{
Social business as a development factor in the region with global overhead
}

\author{
Pavla Varvazovska ${ }^{1}$, and Olga Regnerova ${ }^{2}$ \\ ${ }^{1}$ Czech University of Life Sciences, Department of Humanities, Prague, Czech Republic \\ ${ }^{2}$ Czech University of Life Sciences, Department of Trade and Finance, Prague, Czech Republic
}

\begin{abstract}
The social economy is an integral part of the national economy and, as its third sector, carries out economic activities with a social and environmental objective. Social entrepreneurship can be seen as a business activity that thrives on society and the environment. This fact is very important for both local development and global dimension and impact. The main objective of the paper is to propose the possibility of social entrepreneurship as a factor for the development of the region with the aim of sustainable development while respecting the principles of regional and global politics. The results are interpreted on the basis of both quantitative and qualitative surveys and the information obtained will be used to suggest potential social entrepreneurship in the region's development. The recommendations are formulated in favor of promoting the social enterprise sector, which has not only a regional impact, but also a global overlap.
\end{abstract}

\section{Introduction}

The main theme of the article is a social business enterprise, which itself brings regional assistance in addressing the priorities. It is typical of social entrepreneurship that it draws on and uses local resources and thus becomes a benefit for the whole region [1]. It brings together people who would normally never cooperate with each other, thereby losing the region the opportunity to exploit the potential hidden within these people [2].

The article focuses on facts that connect social entrepreneurship with the region and on the possibilities of cooperation of actors not only within social entrepreneurship but also outside with the aim of sustainable development for future generations. The current use of social entrepreneurship as a possible partner in regional development takes place not always in a coordinated way and not always with the support of regions [3].

Social entrepreneurship does not have a clear definition, but in foreign terms this term has been defined for decades in the sense that it is equally important for a social enterprise to achieve profit and increase public benefit. Profit is mostly used for further development of social enterprise. It often creates employment opportunities for people with health, social or cultural disadvantages [4].

The most discussed criteria for a social enterprise are the specific role of individual social entrepreneurs, the position of social innovation, the search for market revenues and the issue of governance [5]. The formulation of the concept of social entrepreneurship is mostly from subjects of subsidies and subsidies. Thus we can meet definitions that are 
similar, but above all adapted to the specific challenges of grant titles, and thus do not directly define the concept of social enterprise, but above all its principles. In theory, the concept of social enterprise can also be considered as a tool for building bridges between the different components of the third sector [6]. In the Czech environment, the concept of social entrepreneurship is difficult to grasp because it overlaps with the concept of entrepreneurship in social services. Social enterprise for understanding meaning can be characterized by economic and social point of view [7].

The cooperation of social enterprises with local actors is part of the principles of social enterprise. The region is also interested in partnership with all the entities that are part of it. However, it is necessary to distinguish between partnership and cooperation. The partnership is connected with formal measures and it has no dimension in which it is about cooperation and cooperation. The opposite is cooperation, where the actors enter into the preparation and implementation of projects together on the basis of common values in the respective locality or region. Together, it means working together, sharing time, human and financial capacities [8].

As can be seen, so-called volunteering in local social enterprises plays a big role in connecting social enterprises with the region. However, most of the benefits of volunteering are uneconomic. Volunteers can play an essential role in meeting environmental and local benefit criteria. The benefits of volunteers for the enterprise can vary. The first is to connect the social enterprise with the local community. Consequently, one of the principles of social enterprise such as local benefit and meeting the needs of the local community is fulfilled. Another benefit is the volunteer ideas and their feedback. The company can then innovate in this way and achieve greater competitiveness. The last option is the use of voluntary activities for administrations in some legal forms of social enterprises. This step also has strategic implications, as the involvement of local actors and people in the business environment can bring the market functioning of the company [9].

From a regional point of view, the quality of the business environment has a significant impact on the long-term economic development of regions. It creates a basic framework for their competitiveness. A high level is considered an important indicator of long-term successful economic development [10]. Funds for own social entrepreneurship can be obtained through European funds. EU funds are the main instrument of European economic and social cohesion (ESC) policy. These funds distribute funds that help reduce economic and social disparities between Member States and their regions.

In a broader sense, social entrepreneurship undoubtedly has a macro-regional and global overlap that blends with the concepts of Corporate Social Responsibility (CSR), which is translated as CSR. The first important feature of CSR is that part of the company's longterm vision is not only the creation of economic profit, but also the creation of intangible assets that are not measurable. These assets mean the future profitability and social strength of the company. In practice, this represents the ability of the company to survive in a dynamically changing environment and the creation of a network of social relationships and ties.

The second important feature of CSR is the principle of volunteering. In practice, this means that the company not only complies with laws and legislative regulations, but voluntarily adheres to moral and ethical principles that go beyond legal standards [11]. Three areas are important for CSR: economic, social and environmental. In these areas, voluntary corporate responsibility for their activities is accepted. Jones suggested instrumental stakeholder theory, according to which CSR is a business tool through which companies gain access to and use of resources and obtain the support of all stakeholders [12]. The CSR concept has its supporters as well as opponents. Milton Friedman is one of the prominent figures in opposing the concept of social responsibility. This Nobel laureate promotes a single corporate social responsibility, which is to create and maximize profits. 
Friedman considers CSR activities to be unprofitable, questionable, and unnecessary waste of business resources that the company could use to generate and maximize profits [13].

There are still critics of the CSR concept in the Czech Republic, who point out that many businesses only create the impression that they are socially responsible. The term 'pinkwashing' refers to a situation in which an enterprise creates the illusion that it is socially responsible. The company impression is thus limited by unrealistic facts. The term 'greenwashing' can be translated freely as green painting. In the specific situation, the company is presenting its activities as ecological, environmentally and socially oriented. In fact, this is not the case. The company deceives not only the customer, but all stakeholders [14]. Business priority is attracting and retaining new customers through competitive advantage through environmental management systems [15]. Sustainable development issues between organizations and their stakeholders are becoming increasingly important worldwide.

In this context, eco-efficiency has become a consistent tool in the transition to sustainable development. Efforts for environmental performance indicators have been used for comparative studies and decision-making tasks that deliver better financial, environmental and social outcomes [16]. If a company fails to adopt at least the basic rules of corporate social responsibility, there may be many situations in the future that will disqualify it from a business perspective. Specifically: sanctions and fines by the authorities [17], higher operating costs, inefficiency of business processes, high staff turnover, company instability, negative public relations, reducing the attractiveness of the company, poor stakeholder relations, bad business image, in the worst case of loss of customers, the reputation of the business and its reputation [18]. Creating and interpreting reports showing corporate social responsibility is time-consuming and costly.

Managers often lose the confidence that the reports contain all the required information and whether they can achieve the desired goals. The information contained in the reports serves to inform and inform all stakeholders [19] Reporting on corporate social responsibility is often influenced by a number of aspects. An important aspect is the sector in which the company operates. More CSR reports can be expected from companies operating in the primary and secondary sectors than companies operating in the tertiary sector. Other aspects are, for example, the size of the company or the area of its operation.

\section{Objectives and Methods}

The main objective of the paper was to find out, based on field research, whether social entrepreneurship is important as a mediator of the region's development. Furthermore, whether it is an important factor in improving local conditions that will benefit all the regional actors involved.

The research questions were divided into three categories. What is the awareness of social entrepreneurs about the region is the first category. The second category is what basic principles of social entrepreneurship are considered important by citizens. What the inhabitants of the regions consider the importance of social entrepreneurship is closed by the research questions. The field survey was carried out in three regions of the Czech Republic (Ústí nad Labem, Zlín and the Capital City of Prague) using a quantitative and qualitative approach. Data obtained from questionnaires were processed statistically and established working hypotheses were confirmed or disproved by statistical non-parametric method. The qualitative data collection technique used semi-standardized interviews with representatives of selected social enterprises and other actors. 


\section{Results and discussion}

All three regions were tested, depending on whether the man or woman knows the goals of social entrepreneurship. For hypothesis 1 at the significance level of 5\%, we reject the null hypothesis (H0) and accept the HA hypothesis, which tells us that there is a certain dependence, that is, there is a statistically significant dependence between knowledge of social entrepreneurship goals and gender.

All three regions were tested, depending on whether education has an impact on the purchase of products or services. For hypothesis 2 at the significance level of 5\%, we reject the null hypothesis (H0) and accept the hypothesis HA, which tells us that there is a certain dependence, ie that there is a statistically significant dependence between the purchase of services or products offered by social enterprises and education.

All three regions were tested, depending on their willingness to work in a social enterprise and residence. For hypothesis 3 at the significance level of 5\%, we reject the null hypothesis (H0) and accept the hypothesis HA, which tells us that there is a certain dependence, that is, there is a statistically significant dependence between willingness to work in a social enterprise and permanent residence. On the basis of these data, it can be concluded that social entrepreneurship is partly unknown.

Most of the respondents associate the term primarily with social services. The public perceives positively the impact on the local region and the support for social enterprises would see most in the support of subsidies and tax. A relationship was found between permanent residence and the willingness to go to work in a social enterprise. There can be seen space for regions that should focus on promoting social entrepreneurship and raising awareness of this form of entrepreneurship and conducting surveys on how well the population is informed about social entrepreneurship. The largest number of social enterprises is in the Capital City of Prague, despite the fact that the willingness to work in a social enterprise is lower in this region.

Another dependency that has been identified concerns the relationship between educational attainment and the purchase of goods or services from social enterprises. More people with a school-leaving exam have opted for the option that people would rather not buy these products or services. Further confirmation of the hypotheses that have been calculated would require additional questions to clarify the reasons why a large proportion of people with a school-leaving examination are not willing to buy social enterprise products or services. The method of semi-structured interviews was chosen for qualitative research, where the topics of the questions the interviewer will ask. On the basis of a qualitative survey, it can be stated that social entrepreneurs lack support from regions. They welcome mutual cooperation between other social enterprises, but they do not use this possibility so often. Rather, they cooperate with non-profit organizations, churches, charities and associations.

The interview participants emphasize adherence to the basic principles of social entrepreneurship and not the purposeful job creation and employing only the disadvantaged. Economic problems are confirmed by all actors. Some even ceased their activities because they did not receive a subsidy or grant and could not continue their work even if they followed all the principles of social entrepreneurship. If the addressed representatives of social enterprises could comment on the proposed Social Entrepreneurship Act, most of the interviewees did not know the draft Social Entrepreneurship Act directly. But they assume that they should not give them more duties than is normal for normal businesses. The law should rather make their business easier and simpler. Most participants in the interview did not confuse the concept of social entrepreneurship with the concept of entrepreneurship in social services. 
Only two said they are working with a church organization that deals with welfare services. Social entrepreneurial actors positively evaluated the interest, or rather the astonishment, of people who are interested in their products or services and appreciate their involvement in such a business, which usually does not bring much profits and still supports the local region. An interesting fact that emerged from the survey is that some social entrepreneurs call their business social. But in the end they only employ disabled citizens. There may be several reasons.

The main thing is obviously that they do not know the principles of social entrepreneurship and they think that this is a sufficient reason to be a social enterprise. How simple it would be if social entrepreneurship was not only a mission but also a livelihood for life. Unfortunately, as the interviews show, most social entrepreneurs are struggling with financial problems and the region has not yet provided them with any support or financial assistance to support their entire business. All interviews show that regional aid is almost zero and so often their business ends.

The question is whether, if the social enterprise would use any of the announced subsidies, it would ultimately be successful and the financial support would sufficiently cover their activities. The analysis of the data shows that some social enterprises have just stopped their activities because they did not receive a grant and it was already unbearable to continue their activities.

\section{Conclusion}

The field survey and the discussion of the results show that residents of all three regions who answered questionnaire questions and participated in the research would welcome social entrepreneurship if it were enacted. It would thus be given a legal form which would mean a clear definition of social entrepreneurship. Regions should support social entrepreneurship more, especially in the form of subsidy programs. Given that social enterprises often access private or government grants outside their own trading income, it may be difficult to implement a social enterprise in organizations with a certain capacity.

Regions should be more interested in businesses that employ disadvantaged people and thus increase employment and thus actually solve the social problem for them. In case that a suitable grant program is not found, another solution is to support individual projects of selected groups that solve the local problem. An example could be again the Ústí nad Labem Region, which has been announcing a grant program for all hospitals in its region for the fourth year "Support of increasing the comfort of patients in providing acute bed care in the Ústí Region:"

These two programs allow all hospitals, regardless of owner or form of business, to apply to the county for a subsidy to acquire equipment that would increase patient comfort. The development of social entrepreneurship as any business is based primarily on raising financial resources. So far it has not been regulated by legislation, but due to the prepared law we could expect it in the next period. Given the support for small and medium-sized enterprises, in which we can also include social entrepreneurship, it should also be mentioned that the new law should not have a significant impact on the administrative burden of social entrepreneurship. It should only regulate the rights and obligations of social entrepreneurship, which in its essence, by the principles of social entrepreneurship most adheres.

The need for legislation to regulate social entrepreneurship is a precondition without which it will be difficult to introduce major concessions for social entrepreneurs. Despite these facts, the operational programs partially support social enterprises. According to studies, the future of this form of business is mainly in cooperation with various types of organizations, forms of business, whether state institutions or private entrepreneurs, or in 
recent decades a modern concept of cooperation through clusters. Social entrepreneurship has become a growing area of interest in research. Research into social entrepreneurship so far has been subdued because of the comparison or measurement model. Rather than lengthy defining social entrepreneurship as an organizational form that an enterprise has or does not have, it would be appropriate to characterize indicators or factors for measuring social entrepreneurship. So far, the authors have most frequently proposed scaling items for the three central components of social entrepreneurship, namely the objectives of social change, business activities and inclusive governance. Thus, the measure measures three identifiable formative dimensions [20].

Public opinion and the need for people to participate in solving the problem are associated with concessions that are able to solve each other on the one hand, the state, the regions and on the other hand social enterprises. On the part of the state, the restriction means less administrative bureaucracy in relation to social entrepreneurship actors in the form of easier access to information and subsidies. On the side of the actors, there is a need for greater consistency in observing the principles and not confusing or abusing the position of a social entrepreneur. Employing only disabled people cannot be accepted as the main principle of social entrepreneurship. Access to the labor market is very limited for disadvantaged groups and in this context this form of entrepreneurship is unattractive and very complex for entrepreneurs.

The field of the collaborative economy is characterized by wide spectrum of suistainability oriented grassroots initiatives such as cooperatives, social businesses, associations and informal initiatives [21]. Social entrepreneurship should focus on innovation and investment, as well as social entrepreneurship is seen as a business that has lead to profit. Social enterprise is a contested concept which has become a site for policy intervention in many countries [22]. With these instruments, it strengthens its competitiveness not only in the region, but also addresses many more people who can thus participate in the common goal of local benefit. This area is also supported by the Organization for Economic Co-operation and Development (OECD) with the project "Stimulating Social Entrepreneurship and Social Innovation" in cooperation with the European Commission [23]. The aim of this project is to support policy makers in designing and implementing efficiencies that help the development of social enterprises. Special attention is paid to the conditions that will promote social innovation on both the labor market and in other policy areas, and stimulate local economic development in relation to inter-regional and global development.

\section{References}

1. D. Popescu Ljungholm, Employee-Employer relationships in the Gig economy: Harmonizing and consolidating labor regulations and safety nets, Contemporary Readings in Law and Social Justice 10, 144-150 (2018)

2. D. Letcher, Online political participation, collective action events, and meaningful citizen engagement: Social media use during mass protests, Geopolitics, History, and International Relations 10, 70-75 (2018)

3. J.M. Šafránková, M. Šikýř, Work expectations and potential employ-ability of millennials and post-millennials on the Czech labor market, Oeconomia Copernicana 8, 585-599 (2017)

4. TESSEA ČR, z.s. Nestátní nezisková organizace. Definice a principy sociálního podniku. [online]. Available: http://www.tessea.cz/tessea-o-nas/definice-a-principysocialniho-podnikani. (2011) 
5. J. Defourny, Focus areas. Social enterprise. [online] Available: https://emes.net/focusareas/ (2001)

6. M. Nyssens, Social Enterprise (1. Routledge, Abigdon, Oxon 2006)

7. M. Dohnalová, L. Průša et al. Sociálni ekonomika (Wolters Kluwer ČR, Praha.2011)

8. M. Pilc, Cultural, political and economic roots of the labor market institutional framework in the OECD and post-socialist countries, Equilibrium. Quarterly Journal of Economics and Economic Policy 12, 713-731 (2017)

9. Z. Trhlínová Khendriche, Partnerství vrozvoji obcí, měst a regionů. (Auditorium.2014)

10. M. Dohnalová et al. Lidské zdroje v sociálních podnicích. (Wolters Kluwer, Praha, 2015)

11. M. Viturka, Kvalita podnikatelského prostředí, regionální konkurenceschopnost a strategie regionálního rozvoje České republiky (Grada Publishinng, Praha, 2010)

12. A.B. Carroll, Corporate social responsibility evolution of a definitional construct. Business and Society 38, 268-295. ISSN 1552-4205 (1999)

13. T.M. Jones, Instrumental Stakeholder Theory: A Synthesis of Ethics and Economics. The Academy of Management Review 20, 404-437 (1995)

14. M.A. Friedman, Friedman doctrine: The social responsibility of business is to increase its profits. The New York Times Magazine [online]. Available: http://umich.edu/ thecore/doc/Friedman.pdf (2018)

15. V. Kunz, Společenská odpovědnost firem. (Grada, Expert Grada, Praha, 2012)

16. H.A. Ferenhof. et al. Environmental management systems in small and medium-sized enterprises: an analysis and systematic review. Journal of Cleaner Production 74, 4453 (2014)

17. R.G. Caiado et al. Towards suistanable development trough the perspective of ecoefficiency. Journal of Cleaner Production 165, 890-904 (2017)

18. K. Koubská and E. Hralová, Společensky odpovědné podnikání jako trend a příležitost: Př́ručka pro malé a střední podniky BECO Group [online]. Available: http://www.cir.cz/prirucka-csr/482649/1985622 (2006)

19. E. Nica, Gig-based working arrangements: business patterns, labor-management practices, and regulations, Economics, Management, and Financial Markets 13, 100105 (2018)

20. C. Brooks and I. Oikonomou, The effects of environmental, social and governance disclosures and performance on firm value: The British Accounting Review 50[online]. https://www.researchgate.net/publication/320881563_The_Effects_of_Environmental_ Social_and_Governance_Disclosures_and_Performance_on_Firm_Value_A_Review_ of_the_Literature_in_Accounting_and_Finance (1995)

21. M. Kannampuzha and K. Hockerts, Organizational social entrepreneurship: scale development and validation. Social Enterprise Journal 15, 290-319 (2019)

22. L. Lambert, T. Dedeurwaerdere, M. Nyssens, E. Severi, O. Brolis, Unpacking the organisational diversity within the collaborative economy: The contribution of an analytical Framework from social enterprise theory. Ecological Economics 164, 106343 (2019)

23. D. Pascal and S. Chris, Social Entrepreneurship: An Affirmative Critique. (EE Publishing, UK, 2018) 